\title{
Reproducing the organic matter model of anthropogenic dark earth of Amazonia and testing the ecotoxicity of functionalized charcoal compounds
}

\author{
Carolina Rodrigues Linhares ${ }^{(1)}$, Jasmin Lemke ${ }^{(2)}$, Ruben Auccaise ${ }^{(2)}$, Daniele Avilez Duó ${ }^{(3)}$, \\ Roberta Lourenço Ziolli( ${ }^{(4)}$, Witold Kwapinski ${ }^{(5)}$ and Etelvino Henrique Novotny ${ }^{(2)}$ \\ (1)Universidade Federal Fluminense, Outeiro de São João Batista, CEP 24020-141 Niterói, RJ, Brazil. E-mail: carolinaorg.uff@hotmail.com \\ (2)Embrapa Solos, Rua Jardim Botânico, no 1.024, CEP 22460-000 Rio de Janeiro, RJ, Brazil. E-mail: lemke.jasmin@gmail.com, \\ rauccaise@hotmail.com, etelvino@cnps.embrapa.br (3)Universidade do Estado do Rio de Janeiro, Instituto de Química, Laboratório de \\ Processos Químicos, Rua São Francisco Xavier, no 524, Pavilhão Haroldo Lisboa, Sala 306, Maracanã, CEP $20550-013$ Rio de Janeiro, \\ RJ, Brazil. E-mail: danieleduo@yahoo.com.br (4)Universidade Federal do Estado do Rio de Janeiro, Instituto de Biociências, Departamento \\ de Ciências Naturais, Avenida Pasteur, no 458, Sala 412, Urca, CEP 22290-240 Rio de Janeiro, RJ, Brazil. E-mail: robertaziolli@gmail.com \\ (5)University of Limerick, Department of Chemical and Environmental Sciences, Carbolea Group, Limerick, Ireland. E-mail: witold.kwapinski@ul.ie
}

\begin{abstract}
The objective of this work was to obtain organic compounds similar to the ones found in the organic matter of anthropogenic dark earth of Amazonia (ADE) using a chemical functionalization procedure on activated charcoal, as well as to determine their ecotoxicity. Based on the study of the organic matter from ADE, an organic model was proposed and an attempt to reproduce it was described. Activated charcoal was oxidized with the use of sodium hypochlorite at different concentrations. Nuclear magnetic resonance was performed to verify if the spectra of the obtained products were similar to the ones of humic acids from ADE. The similarity between spectra indicated that the obtained products were polycondensed aromatic structures with carboxyl groups: a soil amendment that can contribute to soil fertility and to its sustainable use. An ecotoxicological test with Daphnia similis was performed on the more soluble fraction (fulvic acids) of the produced soil amendment. Aryl chloride was formed during the synthesis of the organic compounds from activated charcoal functionalization and partially removed through a purification process. However, it is probable that some aryl chloride remained in the final product, since the ecotoxicological test indicated that the chemical functionalized soil amendment is moderately toxic.

Index terms: Daphnia similis, biochar, chemical oxidation, fractionation of humic substances, nuclear magnetic resonance, pyrogenic carbon.

\section{Reprodução do modelo de matéria orgânica da terra preta de índio e ecotoxicidade dos compostos formados da funcionalização do carvão}

\begin{abstract}
Resumo - O objetivo deste trabalho foi obter compostos orgânicos similares aos encontrados na matéria orgânica da terra preta de índio (TPI) por meio de procedimento de funcionalização química de carvão ativado, bem como determinar a ecotoxicidade desses compostos. A partir do estudo da matéria orgânica de TPI, um modelo orgânico foi proposto e uma tentativa de reproduzi-lo foi descrita. Realizou-se a oxidação de carvão ativado pelo uso de hipoclorito de sódio em diferentes concentrações. Recorreu-se à ressonância magnética nuclear para verificar se os espectros dos produtos formados eram similares aos de ácidos húmicos de TPI. A similaridade dos espectros indicou que os produtos obtidos eram estruturas aromáticas policondensadas, com grupos carboxílicos: um condicionador de solo capaz de contribuir com a fertilidade do solo e com a sustentabilidade de seu uso. Um teste ecotoxicológico com Daphnia similis foi realizado nas frações mais solúveis (ácidos fúlvicos) do condicionador obtido. Cloretos de arila foram formados durante a síntese dos compostos orgânicos a partir do carvão funcionalizado e parcialmente removidos por meio de um processo de purificação. Contudo, é provável que algum cloreto de arila tenha permanecido no produto final, já que o teste ecotoxicológico indicou moderada toxicidade do condicionador obtido.
\end{abstract}

Termos para indexação: Daphnia similis, "biochar", oxidação química, fracionamento de substâncias húmicas, ressonância magnética nuclear, carbono pirogênico.

\section{Introduction}

The "terra preta de índio" - anthropogenic dark earth of Amazonia (ADE), have been shown to have many favorable characteristics compared to other adjacent soils. These characteristics include increased agricultural productivity, great carbon sequestration, low methane and nitrous oxide emission, reduced 
fertilizer use and nutrient leaching, and increased water holding capacity.

ADE soils show high and persistent microbial activity (Woods et al., 2009; Atkinson et al., 2010; Grossman et al., 2010) and high charge densities in their humic components - characterized by hydrogen deficient condensed aromatic structures, consisting of carboxylic groups linked to the aromatic core (Haumaier \& Wolfgang, 1995; Kramer et al., 2004; Liang et al., 2006). The soil organic matter found in ADE has a pyrogenic character (black carbon) that probably came from the cooking and biomass carbonization done by the indigenous population that inhabited the area. Black carbon is a charcoal created by the carbonization of mainly lignocellulosic materials, which is resistant to thermal, chemical and photo-oxidation, and shows great recalcitrance (Novotny et al., 2009; Atkinson et al., 2010). Furthermore, the organic matter of the ADE has not only aromatic structures (pyrogenic carbon) but also carboxylic groups directly linked to them. This is a consequence of the partial oxidation of the peripheral aromatic units of the pyrogenic carbon residues that gives rise to acidic (carboxyl) substituents (Glaser et al., 2001; Kramer et al., 2004; Masiello, 2004; Novotny et al., 2007) and to relatively high total acidity values. These characteristics confer ADE with traits relevant to soil fertility and to sustainability.

Based on detailed investigations of the organic matter from ADE, an efficient model of organic material has been proposed (Novotny et al., 2007). This model involves a compound of polycondensed aromatic structures with carboxylic functionality. Pyrogenic carbon results from the partial combustion of biomass in an oxygen-deficient environment (Bridgwater et al., 1999; Atkinson et al., 2010). It has condensed aromatic groups that guarantee its recalcitrance in the environment (half-life ranging from centuries to millennia) and provide a suitable material for carbon sequestration.

Biochar is the charcoal (pyrogenic carbon) obtained from pyrolysis of biomass and produced for soil application in order to sequester $\mathrm{C}$ and improve soil fertility (Atkinson et al., 2010). In soils, biochar interaction with the environment can form new compounds with carboxyl groups directly connected to the charcoal recalcitrant aromatic structures, contributing to the soil cation-exchange capacity. Despite the fact that this final compound can improve soil chemical, physical and biological properties, it may take a long time to be naturally formed in soils. Moreover, it is important to evaluate the risks that the use of biochar as a soil amendment can represent to the environment.

Ecotoxicological tests reveal whether and in what quantity chemical substances, isolated or in mixtures, are harmful to the environment, and how and where their effects are expected to be shown in living matter. The effects can be acute or chronic and result in death or changes in morphology, physiology and histology, manifesting altered growth, reproduction, metabolism, and behavior of test organisms (bioindicators) (Knie \& Lopes, 2004). These tests provide information about and identify possible risks and negative physical and chemical alterations that the environment can suffer through the introduction of a specific substance. They provide the concentration at which the tested chemical substance has a toxic potential, serving as a preventive system of protection and warning.

The objective of this work was to obtain organic compounds similar to the ones found in the anthropogenic dark earth organic matter using a chemical functionalization procedure on activated charcoal, as well as to determine their ecotoxicity.

\section{Materials and Methods}

Activated charcoal (P.A., Vetec Química Fina Ltda.) was subjected to chemical oxidation using sodium hypochlorite $(\mathrm{NaOCl})$ at six different concentrations $\left(2,3,4,5,10\right.$, and $\left.20 \mathrm{cmol} \mathrm{L}^{-1}\right)$. Five grams of activated charcoal were put in glass beakers with $200 \mathrm{~mL}$ of the $\mathrm{NaOCl}$ solutions at different concentrations. Afterwards, $2.4 \mathrm{~g}$ of $\mathrm{NaOH}$ were added. This resulted in a $0.3 \mathrm{~mol} \mathrm{~L}^{-1}$ concentration of $\mathrm{NaOH}$. The mixture was heated and stirred in a magnetic stirrer-heater $\left(60 \pm 2^{\circ} \mathrm{C}\right)$ for 3 hours, and then filtered. The functionalization of the charcoal was verified through colorimetric analysis of the filtered material, measuring the absorbance at $465 \mathrm{~nm}$, a classical value for studies on humic substances (Orlov, 1985).

The sample was then acidified to $\mathrm{pH} \sim 1$. With this, the humic acid-like fraction (HA) precipitated and the fulvic acid-like fraction (FA) remained in solution. Subsequently, the HA was recovered by centrifugation and dialyzed, and the aliquot of unpurified FA was freeze-dried. The dialyzed FA was purified with XAD-7 and Ambertile IR-120 resins (Swift, 1996). XAD-7 resin is a non-ionic macroporous polymer with a large surface 
area, which permits the selective sorption of humic substances, allowing polar contaminant substances to pass through, enabling the recovery of the adsorbed fraction. In the IR-120 resin, FA is H-exchanged. HA, FA (the purified one), and the XAD-7 excluded polar compounds (XAD-excluded polar fraction) were then freeze-dried.

The HA and the purified FA fractions were analyzed by a variable-amplitude cross-polarization (VACP) solid-state ${ }^{13} \mathrm{C}$ nuclear magnetic resonance (NMR), in a $500 \mathrm{MHz}$ Varian spectrometer (Palo Alto, CA, USA) at ${ }^{13} \mathrm{C}$ and ${ }^{1} \mathrm{H}$ frequencies of 125 and $500 \mathrm{MHz}$, respectively. The experiments were carried out using a magic-angle spinning (MAS) of $14 \mathrm{kHz}$, a cross-polarization time of $1.0 \mathrm{~ms}$, an acquisition time of $15 \mathrm{~ms}$, a recycle delay of $500 \mathrm{~ms}$, and a high-power two-pulse phase-modulation (TPPM) proton decoupling of $70 \mathrm{kHz}$.

The whole $\mathrm{pH}$ range soluble samples (purified and unpurified FA and XAD-excluded fraction) were analyzed in a PerkinElmer Spectrum 400 fourier transform infrared (FTIR) spectrometer (PerkinElmer, Waltham, MA, USA), in the range between 4,000 and $400 \mathrm{~cm}^{-1}$. Then, $\mathrm{KBr}$ pellets were prepared with $1.0 \mathrm{mg}$ of sample and $100 \mathrm{mg}$ of $\mathrm{KBr}$. The amount of dissolved organic carbon (DOC) was also measured, using a Shimadzu TOC 5000 (Shimadzu, Kyoto, Japan), a total organic carbon analyzer. These samples were selected because they have the highest potential risk of water contamination due to their high solubility.

Afterwards, the ecotoxicological acute test was done using the purified FA sample and the planktonic freshwater microcrustacea, Daphnia similis, as a bioindicator (Viganó et al., 2001; Baral et al., 2006; Hamdi et al., 2006). The young individuals (neonates) of $D$. similis were exposed for a period of 48 hours to various dilutions of the purified FA samples.

The cultivation of the organisms used in the test was carried out in the basic medium M4. Basic medium M4 solutions were prepared in volumetric flasks and stored in a refrigerator at $4^{\circ} \mathrm{C}$ under luminosity. Aeration of the water occurred for at least 12 hours to ensure that the salts were solubilized, the dissolved oxygen amount saturated, and the $\mathrm{pH}$ stabilized (Associação Brasileira de Normas Técnicas, 2009).

In the present study, samples of neonates from the third generation were used on susceptible tests with potassium dichromate to ensure that the neonates were healthy. For that, cultures of $D$. similis were kept in an incubator chamber of biochemical oxygen demand, at $20 \pm 2^{\circ} \mathrm{C}$, under a light intensity of 1,000 lux, for a photoperiod of 16 hours. The animals were kept in 2.0 L glass crystallizers with $160 \mu \mathrm{S} \mathrm{cm}^{-1}$ conductivity, 180-200 mg L-1 hardness $\mathrm{CaCO}_{3}$, and above $80 \%$ of oxygen saturation, following the cultivation method (Knie \& Lopes, 2004; Associação Brasileira de Normas Técnicas, 2009).

A preliminary test, with large-spaced concentration solutions of FA $\left(0,12.5,25,50,100\right.$, and $\left.200 \mathrm{mg} \mathrm{L}^{-1}\right)$, was performed to determine the toxic range of the test. Then, six FA concentrations $(0,3,6,12,24,48$, and $70 \mathrm{mg} \mathrm{L}^{-1}$ ) were chosen, and the test was repeated twice, using three replicates each time.

Five neonates were randomly chosen and carefully transferred to each solution tube $(10 \mathrm{~mL})$. The solution tubes were covered with aluminium foil and set in a room with temperature of $18-22^{\circ} \mathrm{C}$, in the dark, for 48 hours. During this period, the organisms were not fed. After 48 hours, the number of mobile organisms per tube was observed and recorded. Then, the median lethal dose for 48 hours of exposure (48 hour LC50) was calculated using the probit function.

\section{Results and Discussions}

The colorimetric analyses (absorbance at $465 \mathrm{~nm}$ ) of the filtered product showed a linear relationship $(p<0.0001)$ between $\mathrm{NaOCl}$ concentration and charcoal solubilization (Figure 1). At $95 \%$ of significance level, the intercept of the regression line is significantly equal

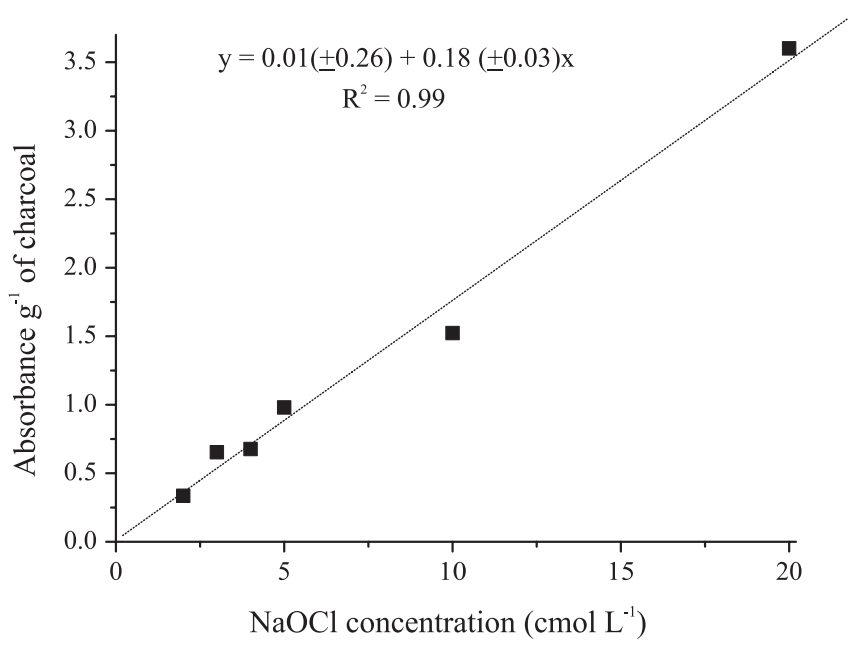

Figure 1. Charcoal solubilization determined by colorimetry (absorbance at $465 \mathrm{~nm}$ ) vs. sodium hypochlorite concentration $[\mathrm{NaOCl}$. Values between parentheses are the $5 \%$ confidence intervals. 
to zero, indicating that the method does not contain additive systematic errors. The linear relationship until the least tested $\mathrm{NaOCl}$ concentration $\left(20 \mathrm{cmol} \mathrm{L}^{-1}\right)$ indicates that the reagent excess is not reached and further studies are needed to determine the optimal concentration.

After the acidification of the filtered solution to $\mathrm{pH} \sim 1$, a suspension was obtained with a soluble (the fulvic acid-like fraction) and an insoluble material (the humic acid-like fraction). This last fraction was still soluble in alkaline medium, which indicates the presence of acid functionalities that promote the acid-basic solubilization characteristic.

The carboxyl functionalization of the activated charcoal was confirmed by VACP-MAS ${ }^{13} \mathrm{C}$ NMR analysis of the obtained products (Figure 2). The acquired spectra were characterized by a featureless aryl peak in the region of $130 \mathrm{ppm}$ and a carboxyl peak at $170 \mathrm{ppm}$. This upfield shift (smaller chemical shift value than the aliphatic carboxyl groups $\sim 175 \mathrm{ppm}$ ) indicates carboxyl groups attached directly to the aromatic backbone. The obtained spectra were similar to the proposed organic model from ADE (Novotny et al., 2009).

Comparing the fulvic acid-like samples with the humic acid-like ones, it was observed that the aryl peak of humic acids showed a smaller chemical shift value (131 ppm) than the fulvic acids prepared with $\mathrm{NaOCl}$ $20 \mathrm{cmol} \mathrm{L}^{-1}(135 \mathrm{ppm})$, indicating that this fulvic acid

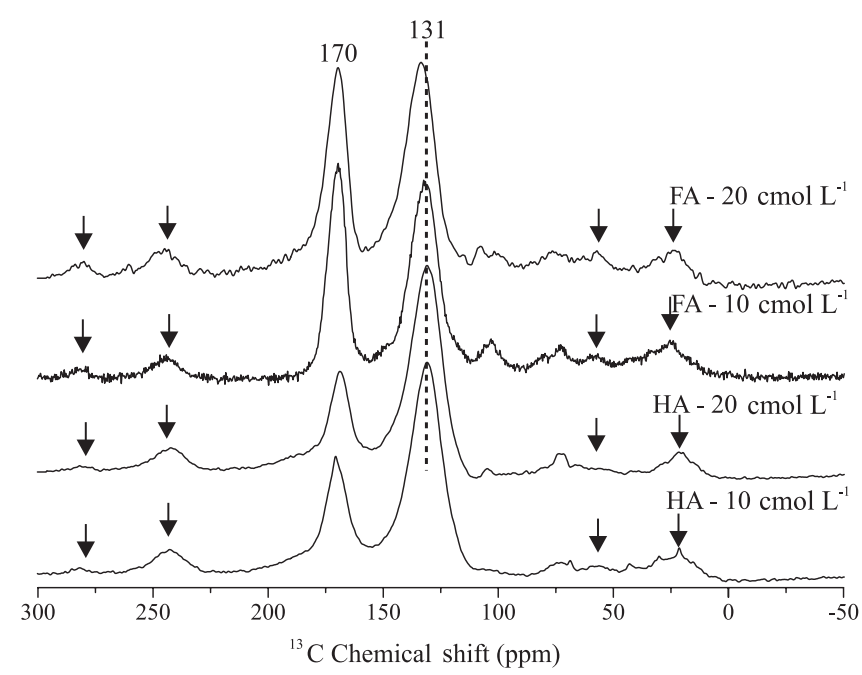

Figure 2. Nuclear magnetic resonance spectra of humic acid (HA) and fulvic acid-like (FA) fractions obtained with $\mathrm{NaOCl}$ concentrations of 10 and $20 \mathrm{cmol} \mathrm{L}^{-1}$. Arrows indicate spinning sidebands. has a less polycondensed aromatic structure. However, the fulvic acids showed higher content of carboxyl groups than the humic acids. These characteristics explain the solubility difference between the fulvic and the humic-acid like fractions. The fulvic acid-like fraction was soluble at any $\mathrm{pH}$ value due to its high functionalization (higher hydrophilicity than humic acids) and low polycondensation degree. The obtained products show two to three times more carboxyl functionalities (the areas of the carboxyl groups are in the range of $27-36 \%$ of the total ${ }^{13} \mathrm{C}$ signal area) than those presented in the literature (Trompowsky et al., 2005). Additionally, the proposed method in the present work was significantly cheaper than the one used by these authors.

The FTIR spectrum of the FA before the resin purification (unpurified FA) showed bands that can be attributed to aryl and carboxyl functionalities (Figure 3). However, bands at $1,120 \mathrm{~cm}^{-1}$, which can be associated to $\mathrm{C}=\mathrm{C}$ stretching of $\mathrm{C}=\mathrm{CCl}$ groups, and at $620 \mathrm{~cm}^{-1}$, to $\mathrm{C}-\mathrm{Cl}$ stretching, indicate the presence of aryl chloride compounds. Aryl chloride compounds are potentially toxic and were probably formed during the functionalization of the activated charcoal, in which hypochlorite was used in the haloformic reaction step. The polar XAD-excluded fraction had a simpler FTIR spectrum than that of the unpurified FA, showing mostly aryl chloride bands. After the purification with XAD-7

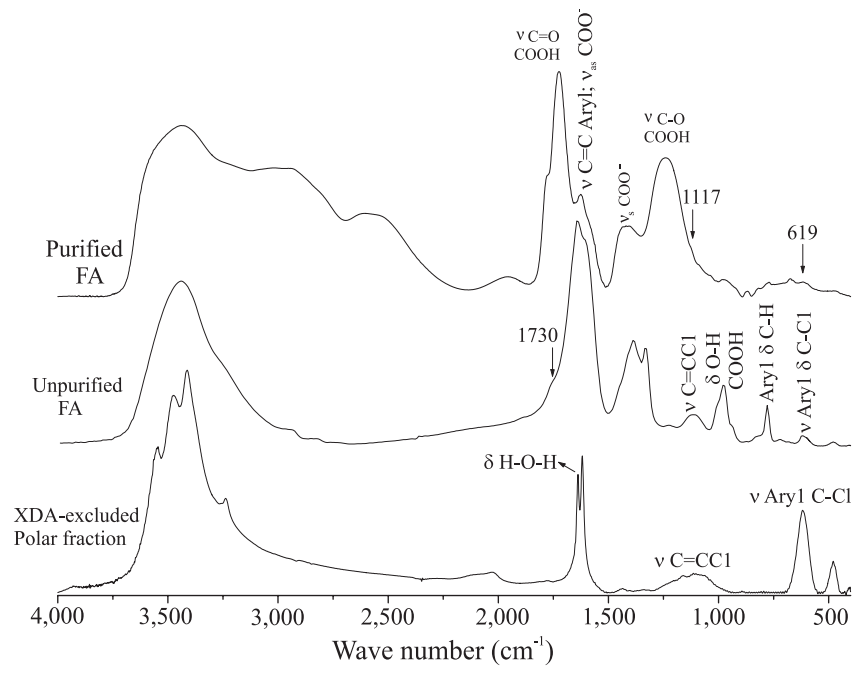

Figure 3. Fourier transform infrared (FTIR) spectra of fulvic acid-like (FA) fraction: purified with XAD-7 resin (upper), unpurified (middle), and polar XAD-excluded fraction (bottom). Infrared vibrational modes: $v=$ stretching $(\mathrm{s}=$ symmetric; as = asymmetric); $\delta=$ bending. 
resin, these bands decreased significantly, being barely visible in the purified FA spectrum, indicating that part of this contaminant can be coadsorbed in the FA.

The presence of bending $\left(1,630 \mathrm{~cm}^{-1}\right)$ and stretching (broad band at 3,500 $\mathrm{cm}^{-1}$ ) bands of hygroscopic water in all samples is probably due to the high hydrophilicity of these compounds. Additionally, the detection of aryl chlorides by FTIR, compounds that were not detected by ${ }^{13} \mathrm{C} \mathrm{NMR}$, corroborates the importance of the use of complementary techniques and contradicts the general non-specialist opinion that ${ }^{13} \mathrm{C} \mathrm{NMR}$ alone is a sufficient analytical tool in any case.

For the ecotoxicological test, the average values for the reference tests with an aqueous solution of potassium dichromate showed a 24 hour LC50 of $1.47 \mathrm{mg} \mathrm{L}^{-1}$. This result guarantees the feasibility of the study with the used population of $D$. similis, considering that they are acceptable within the range of 0.9 to $2.0 \mathrm{mg} \mathrm{L}^{-1}$ (Associação Brasileira de Normas Técnicas, 2009).

The value obtained with the aqueous solution of FA, for the 48 hour LC50, was $21 \mathrm{mg} \mathrm{L}^{-1}\left(7.3 \mathrm{mg} \mathrm{L}^{-1}\right.$ expressed as total organic carbon), with upper and lower limits of 43 and $13 \mathrm{mg} \mathrm{L}^{-1}$, respectively, which classifies the material tested as moderately toxic. This toxicity is probably due to the residual aryl chloride remaining after the purification procedure using the XAD resins. Although the aryl chloride amount was decreased after the resin purification, it was not completely removed. Therefore, further experiments are required, changing the chemical treatment of the activated charcoal, so that the LC50 value will be reduced.

The obtained results indicate the suitability and high sensitivity of the ecotoxicological test using $D$. similis to evaluate new products.

\section{Conclusions}

1. The chemical functionalization of the activated charcoal is effective in producing compounds similar to anthropogenic dark earth of Amazonia.

2. The fulvic acid-like samples are soluble at any $\mathrm{pH}$ value probably due to their high content of carboxylic moieties, resulting in a more reactive compound, and also due to their low aromatic ring condensation, as shown in the NMR spectra.

3. Humic acid-like fraction is only soluble in alkaline solution and has less carboxylic groups, but a more polycondensed aromatic structure, which probably provides a more recalcitrant structure than the fulvic acid-like one.

4. Daphnia similis is a good bioindicator of water pollution, showing that the fulvic acids of the soil conditioner prototype, derived from the chemical functionalization of activated charcoal, are moderately toxic, a result probably related to the presence of aryl chloride in the sample.

\section{Acknowledgements}

To Fundação de Amparo à Pesquisa do Estado do Rio de Janeiro, for financial support; and to Conselho Nacional de Desenvolvimento Científico e Tecnológico and Coordenadoria de Aperfeiçoamento de Pessoal de Nível Superior, for the scholarships granted.

\section{References}

ASSOCIAÇÃO BRASILEIRA DE NORMAS TÉCNICAS. NBR 12713: ecotoxicologia aquática: toxicidade aguda: método de ensaio com Daphnia spp. (Cladocera, Crustácea). Rio de Janeiro: ABNT, 2009. 17p.

ATKINSON, C.J.; FITZGERALD, J.D.; HIPPS, N.A. Potential mechanisms for achieving agricultural benefits from biochar application to temperate soils: a review. Plant and Soil, v.337, p.1-18, 2010.

BARAL, A.; ENGELKEN, R.; STEPHENS, W.; FARRIS, J.; HANNIGAN, R. Evaluation of aquatic toxicities of chromium and chromium-containing effluents in reference to chromium electroplating industries. Archives of Environmental Contamination and Toxicology, v.50, p.496-502, 2006.

BRIDGWATER, A.V.; MEIER, D.; RADLEIN, D. An overview of fast pyrolysis of biomass. Organic Geochemistry, v.30, p.1479-1493, 1999.

GLASER, B.; HAUMAIER, L.; GUGGENBERGER, G.; ZECH, W. The 'Terra Preta' phenomenon: a model for sustainable agriculture in the humid tropics. Naturwissenschaften, v.88, p.37-41, 2001.

GROSSMAN, J.M.; O’NEILL, B.E.; TSAI, S.M.; LIANG, B.; NEVES, E.; LEHMANN, J.; THIES, J.E. Amazonian Anthrosols support similar microbial communities that differ distinctly from those extant in adjacent, unmodified soils of the same mineralogy. Microbial Ecology, v.60, p.192-205, 2010.

HAMDI, H.; MANUSADŽIANAS, L.; AOYAMA, I.; JEDIDI, $\mathrm{N}$. Effects of anthracene, pyrene and benzo[a]pyrene spiking and sewage sludge compost amendment on soil ecotoxicity during a bioremediation process. Chemosphere, v.65, p.1153-1162, 2006.

HAUMAIER, L.; WOLFGANG, Z. Black carbon-possible source of highly aromatic components of soil humic acids. Organic Geochemistry, v.23, p.191-196, 1995.

KNIE, J.L.W.; LOPES, E.W.B. Testes ecotoxicológicos: métodos, técnicas e aplicações. Florianópolis: FATMA: GTZ, 2004. 289p. 
KRAMER, R.W.; KUJAWINSKI, E.B.; HATCHER, P.G. Identification of black carbon derived structures in a volcanic ash soil humic acid by Fourier transform ion cyclotron resonance mass spectrometry. Environmental Science and Technology, v.38, p.3387-3395, 2004.

LIANG, B.; LEHMANN, J.; SOLOMON, D.; KINYANGI, J.; GROSSMAN, J.; O'NEILL, B.; SKJEMSTAD, J.O.; THIES, J.; LUIZÃO, F.J.; PETERSEN, J.; NEVES, E.G. Black carbon increases cation exchange capacity in soils. Soil Science Society of America Journal, v.70, p.1719-1730, 2006.

MASIELLO, C.A. New directions in black carbon organic geochemistry. Marine Chemistry, v.92, p.201-213, 2004.

NOVOTNY, E.H.; DEAZEVEDO, E.R.; BONAGAMBA, T.J.; CUNHA, T.J.F.; MADARI, B.E.; BENITES, V.M.; HAYES, M.H.B. Studies of the compositions of humic acids from Amazonian dark earth soils. Environmental Science and Technology, v.41, p.400-405, 2007.

NOVOTNY, E.H.; HAYES, M.H.B.; MADARI, B.E.; BONAGAMBA, T.J.; AZEVEDO, E.R. de; SOUZA, A.A. de; SONG, G.; NOGUEIRA, C.M.; MANGRICH, A.S. Lessons from the Terra Preta de Índios of the Amazon region for the utilisation of charcoal for soil amendment. Journal of the Brazilian Chemical Society, v.20, p.1003-1010, 2009.

ORLOV, D.S. Humus acids of soils. New Delhi: Amerind, 1985. 378p.

SWIFT, R.S. Organic matter characterization. In: SPARK, D.L.; PAGE, A.L.; HELMKE, P.A.; LOEPPERT, R.H.; SOLTANPOUR, P.N.; TABATABAI, M.A.; JOHNSTON, C.T.; SUMNER, M.E. (Ed.) Methods of soil analysis. Part 3. Chemical methods. Madison: Soil Science Society of America, 1996. p.1018-1020.

TROMPOWSKY, P.M.; BENITES, V.D.; MADARI, B.E.; PIMENTA, A.S.; HOCKADAY, W.C.; HATCHER, P.G. Characterization of humic like substances obtained by chemical oxidation of eucalyptus charcoal. Organic Geochemistry, v.36, p.1480-1489, 2005.

VIGANÓ, L.; ARILlO, A.; FALUGIS, C.; MELODIA, F.; POLESELLO, S. Biomarker of exposure and effect in Flounder (Platichthys flesus) exposed to sediments of the Adriatic sea. Marine Pollution Bulletin, v.42, p.887-894, 2001.

WOODS, W.I.; TEXEIRA, W.G.; LEHMANN, J.; STEINER, C.; WINKLERPRINS, A.M.G.A.; REBELLATO, L. (Ed.). Amazonian dark earths: Wim Sombroek's vision. Berlin: Springer, 2009. 502p.

Received on January 30, 2011 and accepted on April 17, 2012 